\title{
THE ART OF HUNGER: AUTODESTRUCTION AND RESISTANCE IN PAUL AUSTER'S MOON PALACE
}

\author{
María Laura Arce Álvarez, Universidad Complutense de Madrid ${ }^{1}$ \\ Email: marialaura.arce@pdi.ucm.es
}

\begin{abstract}
In his novel Moon Palace (1989) Paul Auster depicts the urban experience of a character who, under the pressure of his urban and social environment, starts a process of autodestruction of his body and identity as a metaphor of the relationship between the individual and the America of the 1960s. In this article, my intention is to show how Auster uses hunger and autodestruction to create a space of resistance against American society and the American dream and thus imagine a new identity of the American individual by creating a new existential space.

Keywords: American Literature, Postmodernism, Urban narrative, Theory of Literature, Comparative Literature.

Título en español: "El arte del hambre: autodestrucción y resistencia en El palacio de la luna de Paul Auster"

RESUMEN: En su novela El palacio de la luna (1989) Paul Auster describe la experiencia de un personaje que, bajo la presión urbana y social de su entorno, comienza un proceso de autodestrucción de su cuerpo y su identidad como metáfora de la relación entre el individuo y la América de los años sesenta. En este artículo, mi intención es mostrar como Auster utiliza el hambre y la autodestrucción para crear un espacio de resistencia contra la sociedad americana y el sueño americano y así imaginar una nueva identidad del individuo americano creando un nuevo espacio existencial.

Palabras clave: Literatura norteamericana, Posmodernismo, Narrativa urbana, Teoría de la literatura, Literatura comparada.
\end{abstract}

In 1989 Paul Auster published his fourth novel, Moon Palace, a work that comes after two of the most important novels written by Auster, The New York Trilogy (1987) and In the Country of the Last Things (1987). According to Debra Shostak, in Moon Palace "Paul Auster addresses the epistemological contradiction between a poststructuralist reality as constructed by the subject through language and an acknowledgment of materiality and the real of referential history" (Shostak, 2008: 149). Moon Palace can be defined as a novel that contrasts the essence of the artist as a creator of stories and the fracture he suffers with the social environment that surrounds him. This is the reason why Paul Auster focuses his plot in the figure of Marco Stanley Fogg, a young American surviving in the New York

Date of reception: 19 October 2014.

Date of acceptance: 24 November 2014. 
of 1969. Aliki Varvogli states in her book The World that is the Book (2001) that in Moon Palace "Auster considers a wider intertext and addresses the question of identity taking into account not only linguistic but also socio-historical factors" (Varvogli, 2001: 124). She also states that "it is the first work in which the author engages in questions pertaining to American history and mythology" (Varvogli, 2001: 124). Among all the different themes presented in the novel, hunger and auto-destruction become the tools chosen by the character in order to first of all, disconnect from a world that does not represent him, secondly start a process of erasure of his identity, which was totally conditioned by that world unsuitable for him, and finally hunger as the root of a voluntary isolation from the world which pushes the young man to recreate his own world. The intention of this article is to show how Auster uses hunger and destruction in his novel Moon Palace as metaphors to represent the creation of a space of resistance in American society and to imagine a new identity of the American individual by creating new stories.

The novel starts by locating the most important events of the action in the summer of 1969: "It was the summer that men first walk on the moon" (Auster, 2004b: 1). Some lines after this opening, the central character, Marco Stanley Fogg, goes back to 1965 and tells how he first arrived to New York City to study at Columbia University. As the first lines of the novel show, the protagonist is living one the most intense periods of the sixties in the United States, an era that according to Daniel Snowman and Malcolm Bradbury the American radical tradition "went back to the Revolution itself, the New England reformers, and the progressive movement of the early twentieth century had come to its peak aided by the ideas of the New Left of Europe" (Bradbury, 1990: 324-325). This is the historical situation in which Marco Stanley Fog frames the story of his life, which is not only the narration of the events that occurred to him during the last year of the sixties, it is also the description of his origins and therefore his identity. In the creation of this character, Auster uses a lot of references of world traveling, the discovery of new worlds and especially the invention of new realities, something he will progressively link in the course of the narration with books and language. One of the most remarkable passages of the novel that introduces these references deals with the protagonist and the origin of his name:

Uncle Victor loved to concoct elaborate, nonsensical theories about things, and he never tired of expounding on the glories hidden in my name. Marco Stanley Fogg. According to him, it proved that travel was in my blood, that life would carry me to places where no man had ever been before. Marco, naturally enough, was for Marco Polo, the fist European to visit China; Stanley was for the American journalist who had tracked down Dr. Livingstone 'in the heart of darkest Africa'; and Fogg was for Phileas, the man who had stormed around the globe in less than three months. (Auster, 2004b: 6)

It can be interpreted from this passage that both concepts of discovery and invention mark the protagonist's name and consequently identity. Furthermore, if Auster is associating the themes of discovery and invention with identity, thus he is taking the reader back to the discovery of America and its consequent European reinvention. Following Bradbury's and Snowman's words, they state that "To many Americans it appeared that the long radical history of the United States, a nation founded on revolutionary principles, was now coming to its fulfilment, and the future of the capitalist system itself was in doubt" (Bradbury, 1990: 
324), it can be inferred the interpretation of an intimate relation between the sixties and the origins of America in which the sixties represent the radical manifestation of those values coined at the beginning of the "new founde land". Thus, Marco Stanley Fogg represents these first principles which now Auster questions in the context of the America of the sixties.

This is not the first time that Auster introduces the idea of a reconstruction of the American society and the American individual by returning to its origins. Certainly his first novel City of Glass (1985) deals with this topic concretely focused in the figure of Peter Stillman Sr's and his scientific project that, at the end, is the origin of the detective case presented in the novel. This character proposes a whole project in order to recuperate the language spoken in the Garden of Eden and therefore save America from the original fall (Auster, 2004a: 42-49) in the middle of a postmodern New York. As in Moon Palace, Auster introduces a character that needs to reconstruct not only his urban space but also his own identity as a consequence of it.

After the death of his uncle, Fogg inherits more than a thousand books, concretely 1.492 books in boxes that, at the beginning, he is going to use as pieces of 'imaginary furniture' (Auster, 2004b: 2): "grouping the cartons into various modular configurations, lining them up in rows, stacking them one on top of another, arranging and rearranging them until they finally began to resemble household objects" (Auster, 2004: 2). The number of books is very significant bearing in mind that they remind the reader to the year of the discovery of the new world. Again, a possible connection between the protagonist and his intention of creating a new is introduced in the text. Moreover, the reference to the new world is related to books in this context as objects that contain imaginary and of course unknown worlds. Concretely, these boxes turn into the puzzle, as the narrator calls it, which will conform the space where Fogg lives. At the same time, these boxes, full of words, will fill up Fogg's world with new stories that reconstruct his existence. He states:

Think of the satisfaction, I would explain to them, of crawling into bed and knowing that your dreams are about to take place on top of nineteenth-century American literature. Imagine the pleasure of sitting down to a meal with the entire Renaissance lurking below your food. In point of fact, I had no idea which books were in which boxes, but I was a great one for making up stories back then, and I liked the sound of those sentences, even if they were false (Auster, 2004b: 2).

In my opinion, Auster chooses particular periods of American literature which at the end build up the identity of America. In other words, these texts are not only part of Fogg's identity, they are also pillars in the construction of the American self. In the chapter "New Founde Land" Ellman Crasnow and Philip Haffenden affirm that:

America was, it has been said, not so much discovered as invented, and come into existence very much as a result of ideas already attached to it by men elsewhere. This 'New Founde Land', then, is obviously not natural and given. And the student rediscovering the presuppositions of its identity is thus well placed to examine the experience of a culture in which the problem of definition is, right up to the present, a continuing preoccupation (Bradbury, 1990: 31).

In this context, Fogg includes the texts and stories inherited by his uncle. Through the central character, Auster is showing a way of reconstructing and reinventing America in 
a time of radical changes and social agitation. In order to do so, Fogg uses the books and boxes as his tower of Babel, a symbol that refers back to Auster's first novel The New York Trilogy and of course a symbol that illustrates the creation of a new world and the creation of languages back in ancient times. Ultimately, it is the creation of an imaginary space, that the narrator admits he is moving to and, in this way, this space becomes his place of resistance to fight against a system which is not representing him.

Among the main themes that inspired this novel, there are two, which are also recurrent in other novels, and those are the topic of hunger and isolation. Both are linked since it seems that isolation is the previous step that takes the character to a total state of abandonment and starvation. As his economic situation gets worse, food becomes a privilege in his life. He does his best to fulfill this natural need but at the end becomes a very difficult task. Likewise, hunger turns into one of the first symptoms that predict the transformation of the character into a vagrant. Characters such as Daniel Quinn in City of Glass (1985), Anna Blume in In the Country of the Last Things (1987) or Willie G. Christmas in Timbuktu (1999), will experience extreme situations of hunger as Marco Fogg will:

I did not starve, but there was rarely a moment when I did not feel hungry. I often dreamt about food, and my nights that summer were filled with visions of feasts and gluttony: platters of steak and lamb, succulent pigs floating in on trays, castlelike cakes and desserts, gigantic bowls of fruit. During the day, my stomach cried out to me constantly, gurgling with a rush of unappeased juices, hounding me with its emptiness, and it was only through sheer struggle that I was able to ignore it. By no means plump to begin with, I continued to lose weight as the summer wore on. Every now and then, I would drop a penny into a drugstore Exacto scale to see what was happening to me. From 154 in June, I fell to 139 in July, and then to 123 in August. For someone who measured slightly over six feet, this began to be dangerously little. Skin and bone can go just so far, after all, and then you reach a point when serious damage is done (Auster, 2004b: 28-29).

For Marco, hunger turns into a constant state up to a point in which it seems to be finally inscribed in his body as an irreversible damage. However, hunger becomes a sort of passage to a blurred realm in which reality and fantasy are confounded. Indeed, Marco talks about conscious hallucinations that do not put him on the verge of madness but opens a new perspective for him in his austere existence. In this particular theme, Auster's fiction is influenced by two different works: Hunger (1890) written by the Norwegian author Knut Hamsun, and Kafka's short story "The Hunger Artist"” (1924). Actually, Auster publishes in 1970 an essay titled "The Art of Hunger" that analyses Hamsun's novel. Whereas the first work presents a poor journalist who tries to survive in the streets and constantly looks for money to eat, Kafka's story portrays an artist who is proving himself by not eating, and exhibits his experiment to others. In my opinion Auster unites the message of these two works and fuses them to create different fictional passages in his works. On the one hand, Hamsun's work would represent hunger as the fracture of the individual with society, the

\footnotetext{
2 Herman Melville's short story Bartleby, the Scrivener (1853) deals with the topic of starvation as a weapon for resistance against the system. The most remarkable metaphor for this is the protagonist's constant repetition of the statement "I would rather prefer not to" and his total physical abandonment in a small corner of the office where he works. From this perspective, Marco Fogg's experience has a lot of common things with Bartleby in his behavior and experiment.
} 
obstacle to integrate in the system. Certainly, in his essay "The Art of Hunger", Auster states in relation to this work: "Having withdrawn into a nearly perfect solitude, he has become both the subject and object of his own experiment. Hunger is the means by which this split takes place, the catalyst, so to speak of altered consciousness" (Auster, 2003: 319). On the other hand, Kafka's short story symbolizes the idea of the limits of art and how the artist is willing to give his life for it. In his article "Community and Interpretive Communities in Stories by Hawthorne, Kafka and García Márquez" Ronald E. McFarland asserts in relation to Kafka's short story "The hunger artist, as several commentators have argued, may represent the plight of the artist who is misunderstood by the world" (McFarland, 1992: 552). Remarkably, McFarland focuses his reflection not only in the existential condition of the artist but also explains the relationship of the "hunger artist" with the world that surrounds him in the following terms: "The differentness of an individual somehow sets him apart from the community; the community isolates him or in some other way repudiates that individual; the individual dies or departs without a fully satisfactory reconciliation with the community or without an adequate explanation" (1992: 553). Contrary to Kafka's hunger artist, Marco Fogg does the opposite action. Instead of being directly repudiated by the community and forced to abandon it, the protagonist of Moon Palace isolates voluntarily but inside the community creating a micro-cosmos. Apart from this, he reaches a successful reconciliation with the community and returns as a different individual once his friend rescues him. Therefore, in these terms, Auster offers a reinterpretation of Kafka's short story but with the same existential issues.

Still, the isolation that goes together with the process of voluntary hunger entails an unavoidable interaction with the others that inhabit the same social space. In the work The Hunger Artists (1993), Maud Ellman discusses both works and she states that Kafka's "A Hunger Artist" presents a moral whose message implies that "it is not by food that we survive but by the gaze of others; and it is impossible to live by hunger unless we can be seen or represented doing so" (1993: 17). In relation to this, Ilana Shiloh argues that "although the hunger artist seems to be the sole completely satisfied spectator of his past, he survives only as long as there are other spectators who witness his act" (Shiloh, 2002: 143). Furthermore, she concludes that "Fogg fares better than Kafka's protagonist, for he is not completely forgotten" (143) since, at the end, he is saved by his friends and put back into society. In my opinion, it could be suggested that Auster's character illustrates both interpretations and the most representative images of the two texts since Fogg understands his trip to isolation and starvation as a way of rewriting his existence, an argument supported by Ellman's statement when she understands that "the drama of starvation unsettles the dichotomy between the fictive and the real" (1993: 16). Likewise, this argument would support the idea of Marco as a character that in his solitude is becoming aware of his condition of an outsider and would blur the limits of Fogg's existence between reality and fantasy in terms of the alternative reality he creates for himself.

Apart from this, Maud Ellman makes an extensive and thorough study of the idea of hunger from different perspectives, including one from the aspect of self-starvation. Also, she applies her study to different cultural fields especially the literary corpus. Ellman starts by defining hunger as an addiction to nothingness and this first association in my opinion links hunger with isolation. Nevertheless, one of the most important reflections Ellman 
makes regarding the idea of hunger is the fact that she considers hunger "a form of speech; and speech is necessarily a dialogue whose meanings do not end with the intentions of the speaker but depend upon the understanding of the interlocutor" (Ellman, 1993: 3). Paradoxically, it can be argued that Fogg's existence turns into a dialogue condemned to reach what can be considered a zero state, to represent the void and autodestruction hunger brings with itself. Together with this, the most evident and immediate manifestation of hunger is reflected in the body. According to Ellman, "the body seems to stand for an incontestable reality, a throbbing substance in a wilderness of signs" (1993:3-4). Of all the different descriptions that Ellman offers of the state of hunger, it is evident that arguments like distortion between reality and fantasy, form of speech or the effects on the body can be interpreted from the perspective that Fogg is undergoing a transformation to turn into a different person in a space created by himself. From my perspective, Auster uses this time the topic of starvation in order to illustrate the construction of an alternative reality and the transformation of the individual. This is the reason why hunger is so intimately related with solitude and a disconnection with the world in his works. Once hunger starts to make its effects on Marco, at the same time it seems he begins to lose his corporeality. Evidence of this physical and existential transformation is the following fragment:

I was trying to separate myself from my body, taking the long road around my dilemma by pretending it did not exist. Others had travelled this road before me, and all of them had discovered what I finally discovered for myself: the mind cannot win over matter, for once the mind is asked to do too much, it quickly shows itself to be matter as well. In order to rise above my circumstances, I had to convince myself that I was no longer real, and the result was that all reality began to waver for me. Things that were not there would suddenly appear before my eyes, then vanish. A glass of cold lemonade, for example. A newspaper with my name in the headline. My old suit lying on the bed, perfectly intact. Once I even saw a former version of myself blundering around the room, searching drunkenly in the corners for something he couldn't find. These hallucinations lasted only an instant, but they would continue to resonate inside me for hours on end. Then there were the periods when I simply lost track of myself. A thought would occur to me, and by the time I followed it to its conclusion, I would look up and discover that it was night. There was no way to account for the hours I had lost. On other occasions, I found myself chewing imaginary food, smoking imaginary cigarettes, blowing imaginary smoke rings into the air around me. Those were the worst moments of all, perhaps, for I realized then that I could no longer trust myself. My mind had begun to drift, and once that happened, I was powerless to stop it (Auster, 2004b: 29).

The most descriptive and relevant line of this passage in relation to the context of this analysis is the statement "I was trying to separate myself from my body" as a way not only of explaining Marco's need to erase his former identity, also as an argumentation to support a clear transformation of the character into a different and invented figure. In other words, hunger becomes a tool of dialogue of the character with his environment and a form of communication with himself in order to change and delete his former identity. Auster describes this situation in his essay about Hamsun's novel: "having withdrawn into a nearly perfect solitude, he has become both the subject and object of his own experiment. Hunger is the means by which this split takes place, the catalyst, so to speak, of altered consciousness" (Auster, 2003: 319). Actually, as the fragment states, Fogg has become both 
the subject and object of his own experiment in a state of urban and reinvented solitude. The next step in the process for Marco is to accept that "I was no longer real, and the result was that all reality began to waver for me" (Auster, 2004b: 29). As this occurs to him, this also happens to Daniel Quinn in City of Glass. In his attempt to solve Peter Stillman Sr's case, he becomes the subject and object of his own experiment since, instead of solving the case, he is the one who finishes locked up in a room with no solution for the investigation.

In most of his novels, Auster presents an individual intimately attached to the urban space he inhabits. In the particular case of this novel, Marco Fogg's project of isolation and hunger is inseparable from the city of New York, concretely from Central Park. Undoubtedly, Central Park can be considered the heart of the city and one of the most remarkable places. Moreover, Central Park becomes a micro-cosmos inside the macro-cosmos that New York represents and in this sense, the perfect place for Marco Fogg to hide and invent an alternative reality suitable for him. Paradoxically, Marco Fogg chooses one of the most crowded places in New York in order to construct and experience his isolation. The French scholar Michel de Certeau formulates the connection between the urban and the existential condition of the individual in his work The Practice of Everyday Life (1984), in which he establishes a reciprocal connection between the city and the subject in a constant interaction. He defines it in the following terms: "This is the way in which the Concept-city functions; a place of transformations and appropriations, the object of various kinds of interference but also a subject that is constantly enriched by new attributes, it is simultaneously the machinery and the hero of modernity" (De Certeau, 1997: 95). As it can be inferred from this fragment, the city stands as a subject that feeds the modern hero and vice versa in a constant feedback. Concretely in relation to this particular topic in Auster's fiction, the critic Corey Andrews in his essay "The Subject and the City: The Case of the Vanishing Private Eye in Paul Auster's City of Glass", reflects about how the individual searches for his own places in the city in order to create his own spaces of contestation. He asserts: "the vanishing of Auster's postmodern subject is not complete: rather, by creating its own maps and narratives within the city-space, the subject forges for itself a political site of resistance and agency" (Andrews, 1997: 62). This distinction coincides with the interpretation of hunger as a radical manifestation of the artist and as a means to fight against the system. In terms of hunger as a demand of the artist, I think it is significant to mention Maud Ellmann's words “The moral seems to be that it is not by food that we survive but by the gaze of others; and it is impossible to live by hunger unless we can be seen or represented doing so" (Ellmann, 1993: 17). In my opinion, it is this idea of the other and particularly the recognition in the other what motivates the protagonist to move his claim to the streets of New York. Although starvation starts as a quest to the limits of the protagonist's individuality in the isolation of the decayed and gloomy apartment, Fogg takes one step further in his adventure and looks for those boundaries that separate the self from the other. In this case, these boundaries can be considered obstacles imposed by a system that does not represent him and makes him feel detached from the American crowd. This is the reason why Fogg decides to jump to the outside and start a new life in Central Park as a homeless in a moment in which, as Auster asserts in "The Art of Hunger", "Reality has become a confusion of thingless names and nameless things for him. The connection between self and world has been broken" (Auster, 2003: 321). On this respect, Debra Shostak distinguishes between the outside in 
the novel, meaning the environment that surrounds the character, "the here and now, the tangible, the vast sensorium pressing down on my skin" (63), and the inside represented by hunger itself as a way of existence to resist and attach to a new reality (Shostak, 2008: 157). This idea is reflected in Fogg's first reflections in the park:

I slept in the park every night after that. It became a sanctuary for me, a refuge of inwardness against the grinding demands of the streets. There were eight hundred and forty acres to roam in, and unlike the massive gridwork of buildings and towers that loomed outside the perimeter, the park offered me the possibility of solitude, of separating myself from the rest of the world. In the streets, everything is bodies and commotion, and like it or not, you cannot enter them without adhering to a rigid protocol of behavior (Auster, 2004b: 55).

Together with this, Auster remarks not only the relationship of the character with the environment, also with the others that interact with him. In relation to this, Mark Brown discusses in his work Paul Auster the connection between Auster's characters and the world he inscribes them in. In order to explain this, he asserts:

His characters need first to locate themselves in the world through a matrix of situated and relational coordinates, before going on to establish stable relationships with others and a coherent sense of themselves. That is to say, in Auster's work, not until the metropolitan subject has established where they are through the landmarks and symbols of a knowable locale, and where that place is in relation to the rest of the physical and social world (and, in turn, how they are connected to it), can they begin the work of 'selfhood' (Brown, 2007: 2).

Although his project seems individual, as Brown asserts, Fogg needs to be recognized by the others in his existential transformation as an attempt to start with his work of selfhood. Likely, this is the reason why Fogg starts to invent a language for the common things that surround him in the park, especially those that are part of his strict routine: "To undercut my squeamishness, I began giving funny names to the garbage cans. I called them cylindrical restaurants, pot-luck dinners, municipal care packages-anything that could deflect me from saying what they really were" (Auster, 2004: 59). At this point of the narration, Fogg is transforming the environment through language, he is making the place his space. It is remarkable that again Auster uses language as the fundamental tool to build up a new world. In this particular fragment, Fogg invents a new language to interact with his new space and accordingly to recreate it. Certainly this transformation is linked to his own physical transformation. Immediately after he tells this new invention, a policeman asks for his ID and looks at him surprised since the change between the picture and his current physical aspect is notorious. Part of this reinvention of the space, of this new creation of Central Park brings with it the transformation of Fogg's identity, the expected result of the process of starvation: destruction of the former identity to invent a new one. But above all, Fogg has reached the point of total auto-destruction. His face and his body were the material manifestations of his existential condition, the inside conquered the outside and his ultimate aim was being accomplished:

In my less exultant moods, I tended to look at myself from a political perspective, hoping to justify my condition by treating it as a challenge to the American way. I was an instrument of sabotage, 
I told myself, a loose part in the national machine, a misfit whose job was to gum up the works. No one could look at me without feeling shame or anger or pity. I was living proof that the system had failed, that the smug, overfed land of plenty was finally cracking apart (Auster, 2004b: 60).

Finally, Fogg is rescued by his friend Zimmer to reintegrate in society. Despite this act can be seen as a defeat, I would argue it is the culmination of a project that has transformed the central character into a different person, an individual aware of reality and who walks in the limits of a system in the same way he wanders around the streets of New York. From this point onwards, the novel focuses in how this new Fogg starts to use his stories and other's stories in order to inhabit his new and own invented reality. Thus, Auster depicts in this novel a way of destroying the walls of the idealized America invented by the founders and radicalized during the sixties in the figure of Marco Fogg, a young American who finds his city and the people that surround him oppressive, nonsense and chaotic. Through the issue of hunger Auster presents a way of resisting against the system and the threshold to transform the central character into an artist who, in the course of the novel, will use different stories to reconstruct his identity and reinvent not only his reality but also the image of America.

\section{REFERENCES}

Andrews, C. 1997. "The Subject and the City: The Case of the Vanishing Private Eye in Paul Auster's City of Glass". Henry Street 6.1, Spring: 61-72. 1999. Timbuktu. London: Faber \& Faber.

Auster, P. 2003. Collected Prose. London: Faber \& Faber. .2003. “The Art of Hunger”. Collected Prose. Paul Auster. London: Faber \& Faber. .2004a. The New York Trilogy. London: Faber \& Faber. .2004b. Moon Palace. London: Faber \& Faber. 2005. In the Country of the Last Things. London: Faber \& Faber.

Bradbury, M and H, Temperley, eds. 1990. Introduction to American Studies. Essex, UK: Longman Group.

Brown, M. 2007. Paul Auster: Contemporary American and Canadian Writers. Manchester: Manchester University Press.

Crasnow, E. and P, HafFenden, eds.1990. "New Founde Land." Introduction to American Studies. Eds. M. Bradbury and H. Temperley Essex, UK: Longman Group.

De Certeau, M. 1997. The Practice of Everyday Life. London: University of California Press.

Ellman, M. 1993. The Hunger Artists: Starving, Writing and Imprisonment. London: Virago Press.

Hamsun, K. 2011. Hunger. Edinburgh: Canongate Books.

KAFKA, F. 2007. The Metamorphosis \& Other Stories. Suffolk: Penguin Modern Classics. 
. 2007. "The Hunger Artist". The Metamorphosis \& Other Stories. Franz Kafka. Suffolk: Penguin Modern Classics.

McFarland, R. 1992. "Community and Interpretive Communities in Stories by Hawthorne, Kafka and García Márquez". Studies in Short Fiction, Vo. 29, Issue 4, p. $551-560$.

Melville, H. 1986. Billy Budd and Other Stories. New York: Penguin Books.

Shiloh, I. 2002. Paul Auster and Postmodern Quest: On the Road to Nowhere. New York: Peter Lang Publishing.

Shostak, D. 2008. "Under the Sign of Moon Palace: Paul Auster and the Body in the Text" Critique, Winter 2008, Vol. 49, No. 2.

Snowman, Daniel and M. Bradbury. 1990. "The Sixties and Seventies". Introduction to American Studies. Eds. M. Bradbury and H. Temperley. Essex, UK: Longman Group.

VARvogli, A. 2001. The World that is the Book. Liverpool: Liverpool University Press. 